Meta

Journal des traducteurs

Translators' Journal

\title{
Discourse Markers in Audiovisual Translating
}

\section{Frederic Chaume}

Volume 49, numéro 4, décembre 2004

URI : https://id.erudit.org/iderudit/009785ar

DOI : https://doi.org/10.7202/009785ar

Aller au sommaire du numéro

\section{Éditeur(s)}

Les Presses de l'Université de Montréal

ISSN

0026-0452 (imprimé)

1492-1421 (numérique)

Découvrir la revue

Citer cet article

Chaume, F. (2004). Discourse Markers in Audiovisual Translating. Meta, 49(4), 843-855. https://doi.org/10.7202/009785ar

\section{Résumé de l'article}

Le rôle des marqueurs du discours est de rendre une conversation cohérente, et plus particulièrement de mettre en relief les intentions du locuteur, et ce qu'il essaie d'exprimer avec ces mots. De façon générale, il n’y a pas de correspondance mot à mot entre deux langues en ce qui concerne les marqueurs du discours. La plupart du temps, leurs équivalents dans la langue-cible n'ont pas le même sens pragmatique, ce qui constitue un risque au moment de les traduire. Dans le domaine de l'audiovisuel, leur traduction est souvent omise pour des raisons de concision ou parce que l'image parle d'elle-même. Le but de cet article est d'examiner la traduction de l'anglais à l'espagnol des particules now, oh, you know, (you) see, look et I mean, dans le désormais film-culte Pulp Fiction, et de s'intéresser à l'impact de leur omission sur l'équilibre entre le sens des relations entre les personnages et le sens de la sémantique.
Ce document est protégé par la loi sur le droit d'auteur. L'utilisation des services d'Érudit (y compris la reproduction) est assujettie à sa politique d'utilisation que vous pouvez consulter en ligne.

https://apropos.erudit.org/fr/usagers/politique-dutilisation/ 


\title{
Discourse Markers in Audiovisual Translating
}

\author{
FREDERIC CHAUME \\ Universitat Jaume, Castelló, Spain \\ uji00096@uji.infomail.es
}

\begin{abstract}
RÉSUMÉ
Le rôle des marqueurs du discours est de rendre une conversation cohérente, et plus particulièrement de mettre en relief les intentions du locuteur, et ce qu'il essaie d'exprimer avec ces mots. De façon générale, il n'y a pas de correspondance mot à mot entre deux langues en ce qui concerne les marqueurs du discours. La plupart du temps, leurs équivalents dans la langue-cible n'ont pas le même sens pragmatique, ce qui constitue un risque au moment de les traduire. Dans le domaine de l'audiovisuel, leur traduction est souvent omise pour des raisons de concision ou parce que l'image parle d'ellemême. Le but de cet article est d'examiner la traduction de l'anglais à l'espagnol des particules now, oh, you know, (you) see, look et I mean, dans le désormais film-culte Pulp Fiction, et de s'intéresser à l'impact de leur omission sur l'équilibre entre le sens des relations entre les personnages et le sens de la sémantique.
\end{abstract}

\begin{abstract}
Discourse markers are mostly used for the production of coherent conversation and, especially, to make clear the speaker's intentions and show what the speaker intends to do with words. In general, there is no one-to-one correspondence between two languages in the field of discourse markers: most of the time their correlates in the target language have not the same pragmatic meaning, constituting a usual pitfall in translation. In the domain of audiovisual translating these particles are often omitted for the sake of brevity or for the meaningful and stroking presence of the parallel image. In this article we will examine the translation from English into Spanish of the particles now, oh, you know, (you) see, look, and I mean, which appear in the cult movie Pulp Fiction and examine how their omission in the translation affects the balance between interpersonal meaning and semantic meaning.
\end{abstract}

\section{MOTS-CLÉS/KEYWORDS}

audiovisual translating, conversations, discourse markers, English to Spanish translations, speaker's intentions

\section{Introduction}

Lexical phrases constitute a somewhat heterogeneous epistemological field that has traditionally been an object of study of philology and has represented a methodological challenge for applied linguistics and lexicology. From a theoretical point of view, in the past its study had been considered essentially anomalous for transformational generative grammar, but it is now recovering prestige both from systemic perspectives and from discourse viewpoints (Salvador, 1995:13-14 and 28). It has also raised a new interest in one of the language industries that has attained its climax at the end of our century: translation studies.

Within the vast field of lexical phrases and idioms, in the present study we will focus our attention on certain units, which function as discourse markers. Some of 
them are still in a process of grammaticalization: they are particles and discursive sequences that have become conventional over the years, but which as yet do not usually appear in the dictionaries as independent entries. Translators must understand the pragmatic meaning of these since, most of the time, their translations are expected to produce the same effect on the addressees of the target text as the source text produced on its own addressees.

And, precisely, the main function of audiovisual translation is to produce a similar effect on the target culture audience as the source text produced on the source culture audience: films, documentaries or cartoons are expressive texts which seek to elicit different emotions from their addressees. In this respect, these texts are intentionally fabricated with a series of linguistic and semiotic devices capable of successfully fulfilling their authors' intentions. Among these devices, one can find our unit's object of the present study: some discourse markers indispensable to the logical composition of ordinary conversation or written discourse, and without which conversation or written discourse would fall apart.

We are going to pay attention to the particles now, oh, you know, (you) see, look, and I mean, particles which clearly help in the production of coherent conversation and, especially, make clear the speaker's intentions and show what the speaker intends to do with words. We have selected these particles because most of the time their Spanish correlates have not the same pragmatic meaning, constituting a usual pitfall in audiovisual translating. For the sake of brevity, we will only analyze exhaustively the particle now, and summarize what happens with the rest of the particles. Conclusions drawn in the analysis of now can be fully applied to the rest of the discourse markers mentioned above.

\section{The Data}

The corpus of this study is based on three different Spanish translations of the American film Pulp Fiction (Quentin Tarantino, 1994): the written translation published by Grijalbo Mondadori (by José Manuel Pomares, 1995), the dubbed version (Lauren Films, 1995), and the subtitled version (Lauren Films, 1995). We are confronting three different modalities of translation: the written (literary) translation of a written text envisaged to be shot, the dubbed version of a film, and the subtitled version of the same film. Thus, conclusions will be drawn according to the modality of translation chosen. We will also be able to compare our three versions from the point of view of the ideology rendered through these particles and the textual operations that the audience may have to make to understand the primary intentions of the source text. We are aware that valid conclusions must be drawn from a larger corpus, but we are also sure that our conclusions can be applied to film translations in the nineties in Spain since the behaviours observed in the translations of this film are literally repeated in every single film translation, especially those addressed to large audiences in commercial cinemas.

\section{The Role of Discourse Markers in Audiovisual Translating}

Within the genre of audiovisual texts, films, documentaries or cartoons are text types characterised by their complex mode of discourse: these texts are expressed through 
images (icons and written texts) and sounds (words, paralinguistic features or music and noises). This inherent characteristic makes them different from other genres in which the translator is allowed to focus his/her attention on verbal discourse alone.

In our case, however, the translation has to match the requirements of the visual image. And this constraint cannot only be overcome by means of synchronising the proper lexis and a good syntactic structure with the visual image: we also need to be coherent in the way ideas are linked and their relation to each other.

It has been widely stated that our competence as readers or addressees of a certain message is such that we tend to extract coherence in texts that lack of coherence, that is to say, taking for granted the cooperative principle, we constantly make an effort to understand the relationships between ideas and units of talk, in spite of the fact that these ideas should be badly connected or simply not connected (Halliday \& Hasan, 1976: 23; Brown \& Yule, 1983:196; Halliday, 1985:301-ff; Fowler: 1986:106; Hatim \& Mason, 1990:194). This is often the case of audiovisual translations, be they dubbed or subtitled versions of a film.

This means that linguistic and textual competence is extremely helpful to understand implicit relations between apparently disconnected ideas, and can make understandable fragments of texts, or whole texts, with implicit cohesive ties hidden among their sentences. Otherwise, the results shown below would lead us to consider audiovisual translations a complete failure.

Let us now see what happens with some discourse markers in the three translations mentioned above.

\section{Now as a Marker of Transition in Thematic Progression}

Following Schiffrin (1987:230) now is a deictic element that "marks a speaker's progression through discourse time, by displaying attention to an upcoming idea, unit, orientation and/or participation framework." It is important, however, not to confound now as a marker or conjunctive element with the adverb now: the adverbial refers to "the time at which a proposition is presented to be true," whereas the discourse marker "occurs in discourse in which the speaker progresses through a cumulative series of subordinate units" (Schiffrin, 1987:228). This is the now we are interested in.

Let us take a look at our examples. Texts are identified as follows: ST= Source Text; WT = Written Translation; DF= Dubbed Film; SF= Subtitled Film. The symbol marks the absence of the discourse marker:

Ex.1- Now (marking a speaker's progression through discourse time, by displaying attention to an upcoming idea, a marker of transition in thematic progression)

Marsellus, a cross between a gangster and a king, is warning Butch, a former boxer, who is to lose a fake combat against a punch-drunk boxer so as Marsellus can get money from it ST Butch, right now you got ability. But painfully as it may be, ability don't last. And your days are about over. Now, that's a motherfucking fact of life, but it's a fact of life your ass is gonna hafta realistic about.

WT (...) Pero, por doloroso que sea, la capacidad no durará siempre. Esto es un jodido hecho de la vida, pero es un hecho de la vida sobre el que tu trasero tiene que ser realista. DF (...) Pero por muy doloroso que sea, la habilidad no perdona. Y tus días se están acabando. Bien, es una ley de vida muy dura, pero (...) 
SF (...) Pero por muy doloroso que sea, la habilidad no perdona. Y tus días se están acabando. Esa es una realidad de esta puta vida, pero es un hecho (...)

Apart from the nonsensical translation of the written text, the failure in the choice of some words like habilidad in the dubbed film, or some odd collocations like realidad de esta puta vida in the subtitled version, we find that the discourse marker now has been lost in the process of translating, both in the written translation and the subtitled translation.

In the source text, now marks an orderly progression through a sequence of subordinate parts, now marks one part of that sequence. Marsellus is trying to convince Butch that his days are over and that is why he has to lose his combat on purpose, get the money Marsellus is offering him in exchange and go away. The absence of now in both versions obliges the audience to make an effort to relate the meaning of both propositions, which are no longer explicitly connected. That's a motherfucking fact of life is connected with your days are over, but without the marker, the translation obliges the audience to guess the relationship between both sentences (in fact, the deictics esto (WT) and, to a lesser extent, esa (SF) are related to the two previous sentences with difficulty). The relationship can be grasped later on when the image shows Marsellus offering Butch an envelope stuffed with dollar bills - the audience will have to wait until that moment to fully understand Marsellus's intentions.

But there is more: now also acts as a marker of sympathy. With that, Marsellus tries to put himself in Butch's place, or at least, tries to make him understand that he sympathises with Butch's feelings, now that Butch knows that his days in the world of boxing are over and he must retire. It serves the purpose of convincing Butch, trying to say "Well, I'm on your side, I know what you feel like now, but face up to it and do what I'm telling you to do." This second interpersonal meaning is also lost, Marsellus tries to do things with words, and the key word here was now.

The dubbed version uses the Spanish connective bien. Unlike its English counterpart well, bien is not always used as a marker of response (Schiffrin, 1987:102 and ff.). It can also be used to mark thematic progression and can be used as a marker of sympathy too. It is colder than other discourse markers that comply with the same function in Spanish and that would have been more explicit here, as far as thematic progression and interpersonal meaning are concerned: mira, for example, could have successfully rendered the pragmatic value of the English now.

As W.J. Ball (1986:85) points out "now is transitional, frequently the opening word from a new speaker, but the same speaker can use it to indicate a new idea or stage within a topic." This is the case in our second example.

Ex. 2- Now (the same speaker can use it to indicate a new idea or stage within a topic)

Lance is telling Vincent the repertoire of drugs he has got at home. After the first sentence, they walk and come into Lance's office. The following scene shows us both characters in a room.

ST Step into my office. Now, this is Panda, from Mexico. Very good stuff. This is Bava (...) Now, the first two are the same (price), but this one... this one's a bit more expensive (...) when you shoot it, you'll notice why (...)

WT Vince, ya puedes entrar. Esto es Panda, procede de Mexico (...) _ L Las dos primeras valen igual, pero...

DT Vamos. Esa es Panda, de Mexico, buena mercancia. Las dos primeras valen igual, pero...

ST___Esta es la Panda, de Mexico, buena calidad. Las primeras valen igual, pero... 
In this second case we have two nows. The first one is clearly used to indicate a new idea. Both characters were talking about piercing before, and now the marker presents a second topic, precisely the main topic: the reason why Vincent has come to Lance's place. We can see that this transition is not explicit in the target texts, neither of them has explicitly connected the second topic with the first one. It does not mean that the translation is worse, we are not concerned here with assessing translation quality. Furthermore, the translation is fully understandable. We are more worried about the mental process the audience has to use in order to put ideas together, in order to understand logical relations between ideas and sentences.

Transition is a property of certain discourse markers that refers to subject matter indicating a change of topic, that is to say, "the previous argument is abandoned and a new topic follows" (Ball, 1986:152). In the film, transition is also marked by the physical transition both characters take, changing from one room to another. This semiotic potential helps the audience to understand that there has been a soft jump between one topic and the next. The Spanish audience can thus capture the intentions of the source text. Once more, the source text is explicitly cohesioned, and coherence comes from both the discourse marker now and the visual support of the scene in which Lance and Vincent go into another room, which semiotically adds to the topic change.

The second now also indicates a new stage within a topic. Drugs are presented in terms of their quality and now it is time to talk prices. Here we see another function of this second now. Not only does it mark a new stage in the conversation (now let's talks about drugs prices) but it also anaphorically advises the audience that a contrast is going to be shown: it is also marking the presence of the connective but that will introduce the idea that the third drug is more expensive because it is better quality and has better effects. The Spanish translations present the connective but abruptly to the audience, with no previous preparation, resulting in a less coherent adversative sentence that can, nevertheless, be understood thanks to the audience linguistic and textual competence.

Finally, it is not admissible to translate the marker now for the Spanish adverbial ahora, a common tendency in translator trainees which seriously affects text coherence: in Spanish ahora either introduces the idea of here and now, or the logical concept of contrast (ahora bien). As we discussed before, the English now can be a time adverb or a discourse marker, whereas the Spanish ahora usually functions as an adverbial or as a discourse marker introducing the pragmatic idea of contrast, just like ahora bien. This is the case of our third example.

Ex. 3- Now (as opposed to the Spanish adverbial or sometimes marker of contrast ahora) In a dance contest, the presenter is showing the prizes to the audience and introduces the participants

ST One lucky couple will win this handsome trophy (...) Now, who will be our first contestants?

(In the Written Translation the whole sentence was omitted)

DF (...) Una pareja afortunada se llevará este maravilloso trofeo (...) ___ ¿Quiénes van a ser nuestros primeros concursantes?

SF (...)Una pareja afortunada ganará este bonito trofeo (...) Ahora, ¿quiénes van a ser nuestros primeros concursantes? 
The idea of contrast that the Spanish ahora introduces in the text is not coherent with the speaker's intentions. The Spanish, bueno could have fulfilled the pragmatic function of the English now, inviting the addressees to answer.

A synthesis of the behaviour of the translations of now is shown in the following table:

TABLE 1

Presence/Absence of Now in the three Spanish versions of Pulp Fiction number of occurrences percentage

ST $\quad 22 \quad 100 \%$

WT $\quad 9$ (8ahora+1bueno) $\quad 41 \%$

DF $\quad 4$ (3bien+1bueno) $\quad 18 \%$

SF $\quad 4(2$ ahora+2bien $) \quad 18 \%$

Besides the question of the (mis)translation of now as a transition marker for the Spanish time adverb ahora - which is only possible in no more than four examples -, we can see that both audiovisual translations have lost most of the nows, obliging the audience to mentally connect the ideas and logical concepts this marker links, that is to say, obliging the audience to make the transition between topics, the thematic progression of the text. As we will see in our conclusions, this process is easier in audiovisual texts. All the same, it does not mean that the marker effects are preserved.

\section{Oh Used in Repair Strategies, in Question-Answer Adjacency Pairs and as an Intensifier}

A quick look at the rest of the discourse markers confirms our hypothesis. Oh is a marker of information management that can be used in question-answer adjacency pairs forcing the answerer to reorient him/herself to information (example 4), in repair strategies (examples 5 and 6), and as an intensifier, "speakers respond affectionately and subjectively to what is said [...] One such subjective orientation is intensity..." (Schiffrin, 1987:95). A speaker is so committed to the truth of a proposition that he/she intensifies his/her feelings through the use of oh (example 7).

Ex. 4- Oh (in question-answer adjacency pairs forcing the answerer to reorient him/herself to information)

The waitress comes to the table where Pumpkin and his girlfriend are planning a robbery. When they realise that the waitress is asking a question, they suddenly reorient themselves to information

ST - Can I get anybody any more coffee? - Oh, yes, thank you

WT - ¿Alguien desea que le sirva más café? - Oh, sí, gracias

DF - (...) Aaaah, eh, sí gracias

$S F-(\ldots) \_$Sí.

Ex. 5- Oh (marker of information management that can be used in repairs)

Brett and his friends have a huge debt with Marsellus. Jules and Vincent have come to their place to kill them all in revenge. Brett was trying to make friends with Vincent and Jules, speaking about hamburgers and drinks. But Jules is fed up with them and suddenly kills one of his friends. Brett can't believe his eyes and falls completely silent. Jules asks ironically: 
ST Oh, I'm sorry, did that break your concentration?

WT Oh, lo siento. ¿Ha interrumpido esto tu concentración?

DF Oh, lo siento. ¿Tal vez te he desconcentrado? Por favor, continúa.

SF __ Lo siento. Te he hecho perder la concentración. Por favor, continúa.

Ex. 6- Oh (marker of information management that can be used in repairs)

Two rapists were sodomizing Marsellus. Although Marsellus wanted to kill Butch before, now Butch feels sorry for him and helps him. He kills one of the rapists and seriously wounds the other one. Marsellus gets free and is concentrated on revenging himself from the humiliation suffered. But Butch is still worried about Marsellus feelings against him and doubts about Marsellus reaction against him

ST - What now?

- What now? Well, let me tell you what now. I'm gonna call a coupla pipe-hittin' niggers and ...

- I meant what now between me and you

- Oh, that "what now?"

WT - Me refiero a qué hacemos ahora entre tú y yo

- Ah, te refieres a eso

DF - Oh, ese ahora qué

$S F-A h$, ¿entre nosotros?

Ex. 7- Oh (as an intensifier)

Jules can't believe Vincent. In Amsterdam, one can take drugs freely at home or at certain authorised places and can get them at certain shops. The police can't stop and search you. It's a right they don't have there.

ST - I mean, that's a right the cops in Amsterdam don't have. - Oh, man, I'm going, I'm fucking going

WT - (...) ___ Eso es todo lo que necesito saber, muchacho. Desde luego que me marcho. DF - Oh, macho, yo me voy allí sin dudarlo. Joder, si me voy allí

SF - __ Yo me voy allí

A synthesis of the behaviour of the translations of oh is shown in the following table:

TABLE 2

\section{Presence/absence of $\mathrm{Oh}$ in the three Spanish versions of Pulp Fiction}

number of occurrences percentage

ST $\quad 16$

WT $\quad 13(11 \mathrm{Oh}+2 \mathrm{Ah}) \quad 81 \%$

DF $\quad 11(6 \mathrm{Oh}+3 \mathrm{Mmm}+1 \mathrm{Ah}+1 \mathrm{Uh}) \quad 68 \%$

SF $\quad 1(1 \mathrm{Ah}) \quad 6 \%$

Two remarks must be made now: the first one is that there is a strong difference between the dubbed version and the subtitled version. The latter shows a striking absence of the discourse marker, so lacking expressivity in the question-answer pair.

The second remark has to do with assessment: the Spanish Oh shows either surprise or disappointment depending on context. These are not the logical concepts that the English Oh shows and that we discussed before. The Spanish Ah usually 
fulfils the functions of repair and question-answer turn taking, and both the Spanish Uh or $\mathrm{Mmm}$ usually fulfil the function of the English $\mathrm{Oh}$ as an intensifier.

\section{You Know Used To Express Confidentiality and Shared Knowledge}

You know is another discourse marker in the process of grammaticalization. Although it does not appear as an independent entry in dictionaries yet, its meaning is gradually drifting away from its literal meaning. In its process of grammaticalization we can distinguish the following pragmatic constituents of this marker: first it is used to express shared knowledge between speaker and listener, or between speaker and the rest of the members of the same culture, that is, "general consensual truths" (Schiffrin, 1987:274). On the other hand, it has a clearly interactional function expressing confidentiality between the speakers, a device used to bring the listener to your own field. This is why it is usually employed in through-arguments, " $y$ 'know appeals to shared knowledge as a way of converting an opponent to one's own side in a dispute" (Schiffrin, 1987:279).

For the sake of brevity, we will just show an example of you know:

Ex. 8- You know (used to express confidentiality)

Somebody has scratched Vincent's new car

ST I just wish I caught 'em doin' it, ya know.

WT Sólo quisiera pescarlos mientras lo hacen, ¿sabes?

DF Ojalá lo hubiera cogido haciéndolo

ST Habría dado cualquier cosa por coger a ese cabrón en el acto

The following table shows the occurrences of you know in the source text compared with the occurrences of its translations in our three Spanish versions:

TABLE 3

$\begin{array}{llc}\text { You know as a marker of alignment in through-arguments } \\ \text { number of occurrences } & \begin{array}{c}\text { percentage } \\ \text { ST }\end{array} & 100 \% \\ \text { WT } & 5 \text { (5 ya sabes) } & 100 \% \\ \text { DF } & 2 \text { (1 ya sabes+1 repetición) } & 40 \% \\ \text { SF } & 1 \text { (1 ya sabes) } & 20 \%\end{array}$

Again two remarks must be made here: first, films are an example of prefabricated discourse. Although film dialogues want to imitate real dialogues, it is striking that in a whole film you know only appears five times. Markers such as you know or I mean are abundant in real conversation. Film dialogues form part of what it is called prefabricated discourse: it imitates reality but cannot include all the hesitations, repetitions and syntactic anomalies that actual oral discourse contains.

The second remark again deals with translation assessment: confidentiality can be expressed in Spanish by the marker ya sabes que..., but just ya sabes followed by a pause sounds artificial. Solutions such as mira, pues (introducing an explanation), oye or sometimes the final interrogative ¿sabes?, can fulfil this function. 


\section{7. (You) See As a Marker of Confidentiality in Through-Arguments}

As Ball puts forward, "what has been said of you know applies equally to you see." Therefore, let us take a brief look at its translations and the percentage of occurrences:

TABLE 4

You see as a marker of confidentiality in through-arguments in audiovisual translating number of occurrences

ST 4 percentage

WT $100 \%$

DF

3 (1mira+1porque+1darse cuenta) $75 \%$ SF 2 (1 porque +1 Oye $)$ $50 \%$ 0 $0 \%$

Again, what is striking is the total absence of the marker in the subtitled version, and to a lesser extent, in the dubbed film. On the other hand, the Spanish Oye and Mira fulfil the interactional function of (you) see, whereas the explicitation of the connective porque serves to link the two logical concepts of both propositions. Solutions provide coherence to the target text, although the Spanish porque loses the interactional meaning that the English you see has.

\section{Look as a Marker of Digression and Reference}

Look is another discourse marker that serves the purpose of managing information. The speaker uses it to set his/her own point "which might otherwise get overlooked amongst other more important matters. The speaker's point or idea is usually relevant, if it were not so, it would be pointless to introduce it into the conversation. It may be necessary to interrupt the speaker" (Ball, 1986:140). This logical concept of digression (parallel to the expression apropos) is shown in the following example:

Ex. 9- Look (as a marker of information management)

Jules had previously asked a boy his name and the conversation had gone ahead. Now the boy is wondering what is Jules' name

ST: Look, what's your name? I got his name's Vincent, but what's yours?

WT: __ ¿Cómo te llamas? Sé el nombre del otro, Vincent, pero, ¿cuál es el tuyo?

DF: Oye, lo siento, no me he enterado de tu nombre. Del tuyo sí, Vicent, pero del tuyo no.

SF: _L Lo siento, no he entendido tu nombre (...)

As a marker of reference, look insists on a topic that has already been discussed, but the speaker may feel that (s)he has not put his/her point convincingly or has not made him/herself clear. So the speaker goes back to the topic. The speaker adds a relevant illustration or corrects a possible misunderstanding by focusing attention on a particular point, as in the following examples:

Ex.10- Look (as a marker of reference)

Marsellus is said to have thrown a man out of the window because the man gave him a foot massage. Vincent has just said that he would never give a man a foot massage, but he wants to make clear that this does not carry with it throwing a man out of the window

ST: Look, just because I wouldn't give no man a foot massage (...)

WT: Mira, el hecho de que yo no le dé un masaje en el pie a un hombre (...)

DF: Escucha, el hecho de que yo nunca masajearía los pies a un hombre (...) 
SF: __ No le daría un masaje a un tío, pero eso no es excusa para tirar a Antwan por la ventana.

Ex. 11- Look (as above)

Dave, the barman, is smiling because he thinks that Vincent will take advantage of his date with Marsellus's wife. But taking advantage of the boss's wife can be really dangerous

ST: (Dave smiles). VINCENT: Look, I'm not an idiot.

WT: Mira, no soy ningún idiota

DF: _ No soy un maldito idiota

SF: __ No soy gilipollas. Es la mujer del jefe

Ex. 12- Look (as above)

Jules is arguing with Vincent, because Vincent is not showing good-manners with Jules' friend, Jimmie, who has helped them both to hide a corpse in his garage

ST: I'm telling you, Vincent, just be cool (...) Look, I ain't threatenin' you.

WT: Te aconsejo Vincent que mantengas la calma. (...) Mira, no quiero amenazarte.

DF: Oye, no te amenazo ni nada, si empleas la cortesía.

SF: Escucha, no te estoy amenazando.

The perception verb look has been well translated by the perception verbs oir and escuchar in Spanish, both conveying the same pragmatic meaning as their English counterpart.

Finally, look also functions as a marker of transition, indicating a change of topic or focusing on some important upcoming idea. This is the case of our final example:

Ex. 13- Look (as a marker of transition, indicating a change of topic or focusing on some important upcoming idea)

Mia is about to die because of an overdose. Lance can save her, but he needs time to look for a medical book that explains how to proceed. So he orders Vincent to speak to her, to keep her conscious, while he looks for the book

ST: Look, just keep talkin' to her

WT: Mira, no dejes de hablarle a ella

DF: Oye, tús igue hablando con ella. Yo iré a buscar el libro (...)

ST: ___ ¡Sigue hablándole! jJody taerá eso! Yo voy a por el libro de medicina

As for the number of occurrences of this marker in the source and target texts, this table again confirms the loss of discourse markers in audiovisual translations:

TABLE 5

Presence/Absence of Look as a marker of digression, transition or reference number of occurrences percentage

ST $6100 \%$

WT $\quad 4$ (4 mira) $\quad 66.6 \%$

DF $\quad 4$ (3mira + lescucha $) \quad 66.6 \%$

SF $\quad 1$ (1escucha) $\quad 16.6 \%$

Again, the absence of the marker is striking in the subtitled version. 


\section{I Mean as a Marker of Clarification}

Another interesting lexicalised clause is undoubtedly I mean. According to Schiffrin (1987:295) “The literal meaning of the expression 'I mean' influences its function in participation frameworks. I mean marks a speaker's upcoming modification of the meaning of his/her own prior talk." It is the realisation of a repair strategy, often said before the listener asks for clarification. It can also be used to add a further explanation. It is really striking that the five occurrences of I mean in our source text have not been translated in the three versions analysed, except for two instances. This can only be understood if we admit, together with Ball (1986:54), that sometimes this phrase is not intended to clarify a point of possible misunderstanding. The message, if any, seems to be: What I am saying/trying to say is..., and as such the link word is not needed. It is addictive and its popularity even with the well educated has no rational explanation." It seems to serve no useful purpose whatever and that is a possible explanation of its total absence in the translations:

TABLE 6

\section{I mean as a marker of clarification}

$\begin{array}{llc} & \text { number of occurrences } & \text { percentage } \\ \text { ST } & 5 & 100 \% \\ \text { WT } & 1(1 \text { es decir }) & 20 \% \\ \text { DF } & 1(1 \text { por ejemplo }) & 20 \% \\ \text { SF } & 0 & 0 \%\end{array}$

I think that the Spanish markers mira and sometimes $o$ sea can fulfil the function of clarification that I mean has. Mira can be used as a precaution to misunderstanding, as exemplifying what has been said before. $O$ sea can serve the same purpose, but it also closes a statement, it can summarise what has been previously said.

But, although I mean may not serve any useful purpose whatever, it can be noticed that it does serve for conveying interpersonal meaning. For the sake of brevity we will only show an example in which the speaker fails in his purpose to clarify what he has said before. Vincent is explaining to Jules what drugs are like in The Netherlands. There Vincent could get the same kind of drugs they have in America but he wants to explain to Jules that there are differences. He uses the phrase I mean, and tries to clarify his point but he fails again and Jules, the listener still needs an example:

Ex. 14- I mean (as a marker of clarification)

$S T$ - It's the little differences. I mean, they got the same shit over there that we got here, but it's just, just, a little different.

- Example?

WT - Las pequeñas diferencias. Ahí tienen la mayor parte de la misma mierda que tenemos aquí pero hay una pequeña diferencia.

- ¿Como por ejemplo?

DF - Pequeñas diferencias. También ellos tienen la misma mierda que aquí, pero hay algunas diferencias.

- ¿Por ejemplo?

SF - Las pequeñas diferencias. Consumen las mismas mierdas que nosotros, pero allí es distinto.

- ¿Por ejemplo? 
Vincent is in the middle of his through-argument, but he fails to explain why it is different in The Netherlands. That is why Jules asks for an example. The three Spanish translations did not acknowledge the marker. I mean and example? bracket Vincent's unsuccessful explanation. Example? is directly related to I mean.

\section{Conclusions}

From the analysis shown in the tables, audiovisual translations would seem to be less cohesioned texts than their source counterparts. Nevertheless, the audience can repair the possible misunderstandings because:

a) Linguistic and textual competence helps the audience to understand less cohesioned texts. We always try to relate sentences and to mentally construct hidden meanings from virtual non-texts.

Moreover, a normal reader or spectator will assume that there are semantic relations between the sentences which display few, if any, explicit markers of cohesive relations. In this sense, Brown and Yule (1983:196) question Halliday and Hasan's assertions $(1976: 2,9,13)$ on explicit cohesive ties as the only source of texture.

b) The image, the visual text that runs together with the verbal text in audiovisual translation, serves as a tremendous help for the audience. Images solve the possible ambiguities that less cohesioned texts may offer.

c) Within the macrogenre of Translations (with capital letters), audiovisual translations, have already become a genre with specific characteristics, easily recognised by their addressees. This genre is already accepted to be less coherent than other genres, the audience accepts deficiencies in cohesion and coherence in audiovisual translations as part of their inherent characteristics.

d) Audiovisual texts are redundant texts par excellence. The same information comes from two channels. Verbal occurrences are many times explained by an image, a gesture, etc., and relevant images are usually explained through words. This is even more explicit in TV series and sitcoms. Therefore, losing discourse markers in the process of translating does not seriously affect the target text in terms of semantic meaning - whereas it does in terms of interpersonal meaning.

We have only studied if audiovisual translations keep or do not keep the source text discourse markers, and maintain the semantic and pragmatic values of the original text. There are more unanswered questions that should be analysed in future research:

1. Does the target language -and the target text - need these discourse markers to be as coherent as the source text? Does the target linguistic system produce coherence through these discourse markers or are there other particular ways of showing coherence? Can this be an explanation for the repeated absence of discourse markers in audiovisual translation?

2. Empirical research would be needed to demonstrate that the absence of connectives is not also due to the bad preparation of translators or to the space and time constraints the translator has to face.

3. Also needed is a more in-depth study on contrastive pragmalinguistics between Spanish and English and a deeper study on translation assessment that may take into account which translations of discourse markers convey the same pragmatic meaning as the source discourse markers. We have put forward that the Spanish adverbial 
ahora fails to be the translation of the English marker now. Likewise, the Spanish Oh - expressing surprise or disappointment - does not convey the same pragmatic meaning than the English $\mathrm{Oh}$ - which expresses repair, intensification, or reorientation to information in an answer, as shown in the examples -. A more detailed and exhaustive study is needed in this field.

4. As far as maintaining intepersonal meaning is concerned, we have to conclude, together with Hatim and Mason, that "given that some elements of meaning must be sacrificed, our interest lies in the kinds of meaning which tend to be omitted and in the effects such omission may have." Few would dispute, in the light of our examples, that "it is difficult for the target language auditors to retrieve interpersonal meaning in its entirety. In some cases, they may even derive misleading impressions of characters' directness or indirectness." (Hatim and Mason, 1997:96). Due to the time and space constraints translators of audiovisual texts have to face, perhaps they prefer to lose interpersonal meaning than semantic meaning, taking for granted that the audience is capable of "interpreting any passage as text, if there is the remotest possibility of doing so." (Halliday and Hasan, 1976:23)

\section{REFERENCES}

BALL, R. (1986): A Dictionary of Link Words in English Discourse, London, Macmillan. Brown, G. and G. Yule (1983): Discourse Analysis, Cambridge, C.U.P. Fowler, R. (1986): Linguistic Criticism, Oxford, O.U.P.

Halliday, M.A.K. and R. Hasan (1976): Cohesion in English, London, Longman. Halliday, M.A.K. (1985): An Introduction to Functional Grammar, London, Arnold. Hatim, B. and I. Mason (1990): Discourse and the Translator, London, Longman.

Hatim, B. and I. Mason (1997): The Translator as Communicator, London and New York, Routledge.

Schiffrin, D. (1987): Discourse Markers. Cambridge: C.U.P.

SAlvador, V. (1995): “De la fraseologia a la Lingüística Aplicada," Caplletra 18, pp. 11-30.

List of sources of text samples

Tarantino, Q. (1994): Pulp Fiction, Lauren Films.

Tarantino, Q. (1995): Pulp Fiction, Lauren Films (Spanish dubbed version).

Tarantino, Q. (1995): Pulp Fiction, Lauren Films (Spanish subtitled version).

Tarantino, Q. (1995): Pulp Fiction: Tres Historias sobre una misma historia..., Barcelona, Grijalbo Mondadori (Written Translation by José Manuel Pomares). 